\title{
PLUTARCH'S LYSANDER AND SULLA: INTEGRATED CHARACTERS IN ROMAN HISTORICAL PERSPECTIVE
}

\author{
José María CANDAu Morón
}

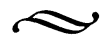

THE TERM ritratto paradossale has been used to describe a formula of character portrayal seen in Latin literature of the first centuries B.C. and A.D. whose basic process consists in combining in one character apparently contradictory traits (La Penna 1976). To be precise, the formula produced a type of man who in his moments of action shows energy, diligence, and constancy but exhibits licentious feelings, allows himself to be taken in by indolence, and succumbs to pleasures when his negotia are finished. This model may already have been present in Greek historical literature of the fourth century B.C., as the portrait of Philip II that the historian Theopompus delineates seems to bear this stamp. The public image of Maecenas and the Petronius of Tacitus are two clear examples of ritratto paradossale. The figure of Sulla also falls under this influence; in fact, according to La Penna $(1976,284)$, Plutarch's biography of Sulla often exhibits these same characteristics.

The terms "paradox" and "paradoxical" also occur frequently in works devoted to Plutarch's Life of Lysander. Its paradoxical features are the central point of Pelling's comments (1988a, 268-74) on that biography. Pelling explores aspects of "integration" in the Parallel Lives, a technique of portrayal which he defines as follows: "a man's qualities are brought into some sort of relation with one another, and every trait goes closely with the next." 1 An almost universal literary habit in the
\end{abstract}

${ }^{1}$ Pelling 1988a, 262. The effect of integration is not exactly the unification, but rather the reconciliation, of the different elements of one character; in this way each trait predicts the next, and the reader easily grasps what idea these may comprise when all taken together. According to Pelling, integrated characters are a familiar element of Greco-Roman literature, and we see this in particularly full expression in Plutarch's biographies. (In contrast we might consider the discontinuity and fragmentation typical of character development in a broad sector of modern literature, e.g., Brecht, Strindberg, Pirandello, Strachey; cf. Pelling 1990, 235-40, 252.) 
ancient world, integration appears even in a figure as complex and full of contrasts as Plutarch's Lysander. Arrogance and cruelty, incorruptibility and a capacity for adulation, duplicity, ingenuity, ambition, treachery: all the contradictions that coexist in him are seen to be unified through philotimia, a central trait that dominates Lysander's other characteristics and gives his portrayal a unified appearance.

But Plutarch's interests in his Life of Lysander do not impel him to explain or reconstruct the traits of its protagonist. It is the contrasts and the paradoxes in Lysander that have drawn the author's attention and lend the biography its particular flavor. Plutarch shows how these diverse character traits work against the individual and end up destroying him. In this way, the biography of Lysander is similar to tragic works in which a character's potentialities unleash forces that ultimately defeat him, and Plutarch explicitly plans on parallelisms with the tragic genre. From this standpoint, Pelling concludes, Lysander offers a moral that is similar to that of tragedy and different from that of other biographies: human nature can produce a figure such as Lysander, and such figures tend to bring about their own destruction through appropriate tragic processes.

Stadter (1992) has recently analyzed from start to finish the paradoxical character that Plutarch assigns to Lysander and also to Sulla, the protagonist of the Roman Life presented as his parallel. In Stadter's view the contradictions in each character-that is, the combination of admirable and repulsive traits - form the basis of the portrayal of both subjects. The biographer also contrives to cross the two Lives so as to convey that they form an ensemble. Among other things, we see a type of progression whose upper limit is delineated by the harshest components of the portrayal of Sulla: his destructive nature, bloodthirsty and implacable, his tyrannical and frequently arbitrary conduct, his arrogance and lack of humanity. These traits are only sketched in the parallel Greek Life; yet their presence there evokes sinister dimensions which horrify when they appear, full-blown, in the Roman counterpart. From this interplay of traits and personalities our understanding of the human type treated in the biographies becomes increasingly deep. The final result in the present instance is that we are enabled to recognize the true traits of Lysander's character, and so escape the difficulty that Plutarch alludes to in his prologue through a cryptic comment on the incomprehensible, brittle disposition of the Spartan general. Despite what its inscription indicates and what many people believe, we are 
told, the statue situated in the treasury of the Acanthians in Delphi represents not Brasidas, an exemplar of Spartan character, but the more complex figure Lysander, who is shown with long hair and beard, in the Spartan style.

Some of the conclusions reached in these recent studies can be questioned. Stadter himself, in a later work, has emphasized how the Parallel Lives invite the reader to measure himself against the protagonists, to consider what his own conduct might be in situations such as those presented there, and to search for the reasons for the actions that are delineated. ${ }^{2}$ But if Pelling is correct, Lysander does not seem conducive to this goal, as its pervasive tragic tone and descriptive moralism $^{3}$ suggest, rather, a composition inimical to the type of inward dialogue ("What would I do in such a situation?") that Plutarch claims to stimulate.

And Stadter, in his effort to accentuate a negative vision of Sulla, does not allow for two important details. First, his emphasis on the somber aspects of Sulla's character does not preclude partial approval of his behavior and his actions. One may come to understand certain declarations in the synkrisis which commend Sulla's efforts to improve Roman customs and unreservedly praise his magnanimity and his capacity to set the public good above his personal interests. ${ }^{4}$ An earlier passage, in the Life of Cicero, points in the same direction. ${ }^{5}$ Second, and more important, the figure of Sulla appears in the biography invested with an aura of grandeur. This receives direct comment in 5.8-11, where it is stated that Sulla was the first Roman from whom the Persians sought alliance and friendship. A Chaldean in the entourage of the Parthian king prophesied the heights to which the Roman general was destined. Notably, in the synkrisis the wars fought by Lysander are described as a "diversion" (trufēn) and "child's game" (paidian) compared to those of Sulla. ${ }^{6}$ But more than anything else, it is the prodigies

${ }^{2}$ Stadter $1997,70,81$

${ }^{3}$ Cf. Pelling 1988a, 274: "Human nature can produce a figure like Lysander."

${ }^{4}$ Sull. 41(3).3, 41(3).8, 43(5).1-5.

${ }^{5}$ Cic. 10.2: "The change which Sulla had made in the constitution at first appeared absurd, but it seemed to the majority, owing to the lapse of time and the familiarity with it, to afford at last a kind of settlement which was not to be despised" (trans. Perrin). In accepting this mixed verdict on the political work of Sulla, Plutarch aligns himself with a substantial part of ancient tradition: see Laffi 1967.

${ }^{6}$ Sull. $42(4) .8$. 
and prophecies that accompany the pursuits and incidents of Sulla's life that give his portrayal the profile of an extraordinary figure. ${ }^{7}$

To sum up: Plutarch's Sulla is a sinister character, cruel and depraved, but also grandiose and the protagonist of an exceptional destiny, and these latter traits are not easy to square with the image that Stadter postulates, which is too centered on the dark aspects. Finally, I suggest that a fundamentally somber view of Lysander and Sulla invites us to see in them an instance of the negative hero, whose clearest representatives are Demetrius and Antony. But this does not seem to have been Plutarch's intention. The prologue of the Demetrius-Antony pair makes it clear that in those two cases the interest lies in the subjects' function as counterexamples; it is through noting their deficiencies that one may extract the relevant lesson by means of an operation $a$ sensu contrario. Furthermore, the synkrisis ends with a comment that casts both under a cloud of ignominy: both of them, Plutarch remarks, died with dishonor, but Demetrius' end was the more dishonorable, as he accepted captivity and lived for years as an animal; Antony also died in infamous circumstances, but he at least cut off his life before falling into the hands of the enemy.

On the other hand, the anecdote about the mistaken statue of Brasidas that opens the prologue of Lysander-Sulla encourages us to penetrate beyond the consensus of opinion and formulate verdicts that transcend appearances. So too, the synkrisis finishes with mention of the virtues by which one or the other excelled. If Lysander and Sulla are paradoxical, it is because their heroes display a mixture of virtues and defects, and the effort that Plutarch makes to distinguish the traces of one trait from those of another ${ }^{8}$ lends this pair a character different than that of the straightforwardly negative Lives. This attempt to convey the mixture of traits that define the men and their destinies is perhaps the most characteristic note in these two biographies. Yet neither Pelling nor Stadter takes it into account.

That being said, the ideas informing Pelling's work (Lysander as an integrated character, despite his contradictions) and Stadter's (the figure of Sulla makes it possible to understand its Greek counterpart) seem to me to be basically correct. Yet I believe that both interpreta-

${ }^{7}$ See note 30 .

${ }^{8} \mathrm{An}$ effort justified by the complexity of the moral problems involved, as the pair Lysander-Sulla deals with people and actions that cannot be simply judged as "good" or "bad": see Duff 1997, 182. 
tions situate these subjects/characters in a context that inhibits free play in assessing their potential and leads to false conclusions. Let us now consider these ideas in a different way.

We may begin with the cultural and historiographical circumstances that surrounded the creation of these paradoxical portraits, and then go on to consider the process that Plutarch uses to introduce paradoxical characters into his biographical works without adopting the literary presuppositions that accompany their birth. The cardinal positioning of Lysander and Sulla in the histories of their respective countries constitutes, in my view, a crucial element in this process. The result is that I prefer to consider these two Plutarchan protagonists not simply as persons, as individual subjects of biography, but also as figures whose characters are linked to a larger plot: the history of Sparta, and of Rome. ${ }^{9}$ Ultimately we shall see how the idea of the Roman Empire and the cultural principles that legitimated its existence served as an ideological standpoint from which Plutarch could judge Sulla and Lysander, weigh their qualities and defects, and make them into characters that can be duplicated by the reader's own experience, thus contributing to their nature as "integrated" characters.

It seems safe to accept La Penna's work and situate the appearance of the ritratto paradossale in Greek literature of the fourth century B.C. If we grant that the key to this style of portrayal lies in contrasting different aspects of an individual character, the most extensive and best-known work of Theopompus, his Philippics, would be full of figures modeled in that manner. Philip II of Macedon, the main character in that work, is portrayed as corrupt, foul-mouthed, incapable of controlling his impulses, and a stranger to morality. ${ }^{10}$ But other important Greek figures were also presented as practitioners of deeds that were licentious, mercenary, or ethically reprehensible. Themistocles was accused of venality, Cimon of ambition and demagoguery. Callistratus, often considered to be the architect of the Second Athenian Confederacy, was described as intemperate (akratess), and Eubulus, the famous Athenian politician of the mid-fourth century, was labeled profligate (as $\bar{o}$ tos). ${ }^{11}$ Connor $(1968,14-15,121-22)$ has observed that this type of char-

9In the sense that Barthes uses the term: see Goldhill 1990, 112-13.

${ }^{10}$ There are many fragments that could be cited in illustration; see, e.g., FGrHist 115 F224. For a general treatment of the theme see Connor 1967.

${ }^{11}$ Themistocles, FGrHist 115 F86; Cimon, F89, with the commentary in Connor 1968, 32-36; Callistratus, F97; Eubulus, F100. 
acter portrayal is based on antithesis: antithesis between reputation and reality, between supposed greatness and anxious stinginess, between political success and moral baseness.

It has become the main task of studies of Theopompus to explain the dichotomy between ethical qualities and political actions. Polybius himself expressed how perplexed he was at the disjuncture in the description of the Macedonian monarch and his companions in the Philippics, between their ethical baseness and the disproportionate extent of their public efficacy. ${ }^{12}$ Various modern authors have tried to give such antitheses an ethical or political significance or tried to explain this feature as a mechanism for explaining a historical event. ${ }^{13}$ Others take antitheses as evidence of the singular and eccentric nature of the Philippics within the tradition of Greek historiography. ${ }^{14}$ This latter observation is only partially correct. Timaeus of Taormina, one of the most widely read and influential Greek historians of his time, earned a reproach similar to the one that Theopompus received from Polybius. In Timaeus' case the reproach came from both Polybius and Diodorus, who considered the greatness of Agathocles' undertakings to be incompatible with the moral baseness that Timaeus attributed to him..$^{15}$

On the other hand, the literature of the fourth century seems receptive to the idea that contradictory traits may coexist within a single individual. The most familiar text in point is the passage from Plato's Phaedrus $(246 \mathrm{a}-\mathrm{c})$ in which the soul is compared to a yoke of horses with opposing tendencies, but other passages with similar content can be found elsewhere in Plato and in Xenophon. ${ }^{16}$ Yet it is true that Theopompus' disjunctures do not easily square with a historiography whose content is political and military and whose purpose is didactic, and it is understandable in this context that Polybius, a decided advocate of the function of history as teacher for public life and tutor for the

12 Plb. 8.10.7-13.8 = FGrHist 115 T19, F27.

${ }^{13}$ Among the most widely known studies on Theopompus are those referred to by Connor (1967, 133-34) and Shrimpton $(1991,129)$.

${ }^{14}$ See Connor 1968, 117; Brown 1973, 118.

${ }^{15}$ Plb. 12.15; D.S. 21.17.1-4 = FGrHist 566 F124b, F124d. The reputation that Timaeus won during the Hellenistic period can be judged by the fact that Polybius dedicates the greater part of book 12 of his Histories to criticizing the methods that Timaeus and his followers used. One can identify in the same vein a work in twelve books by Polemon the Periegete entitled Against Timaeus (FGrHist 566 T26, F24). See also Pédech 1961, 144-45; Lehmann 1974, 161; Pearson 1987, 269-71.

${ }^{16}$ Pl. Rep. 439d-440a, Leg. 896d; Xen. Cyr. 6.1.41, Mem. 1.2.23. 
politician, should criticize the author of the Philippics. Given that didacticism and political applicability are essential ingredients in the works through which we know Greek pragmatic history, it is not surprising that modern philology presents Theopompus as a marginal and eccentric author.

We should remember, however, that our knowledge of Greek historiography, especially that of the Hellenistic period, is riddled with gaps; ${ }^{17}$ there may have existed tendencies widely different from the usual mold of the works that have survived. In fact the literary conditions of the Hellenistic age-the evolution of comedy is a significant example-foretell a historiography in which political didacticism would lose ground, or at least change its orientation. Certain facts that emerge from statements and fragments seem to indicate the emergence of a type of historical work characterized by a removed and theatrical presentation of events. An essential trait of this new historiography was lack of proximity between popular and historical material, a disjuncture played out in the presentation of historical events as spectacle and in the assimilation of historiography to drama. This trait is most visible in so-called tragic historiography, a genre that employed methods similar to those at work in tragedy; the term, introduced by Schwartz (1905a, 1905 b), reflects the terminology that ancient authors used to characterize works of this tendency. Appropriation of dramatic techniques and processes has been detected in the works of Timaeus of Taormina, in his case taken from comedy; signs of this are the parodic tone of his writing, the deformations, the desacralizing treatment of famous personages, and the use of words and expressions taken from the comic tradition. ${ }^{18}$ Callisthenes could also be counted among those following these new tendencies: fragment 44 suggests that he used the language of theater to discuss the task of the historian. ${ }^{19}$

${ }^{17}$ See Strasburger 1977.

${ }^{18}$ FGrHist 566 F35b, F124b, F156, with the commentary in Vattuone 1991, 77-78, 191-94, 36-39. The best-known work of Timaeus, his History of Sicily, does not strictly belong to the pragmatic genre but rather to ethnography; but among ethnographic works the History of Sicily is distinguished by its strong affinity to true pragmatic historiography: cf. Jacoby [1909] 1956, 30.

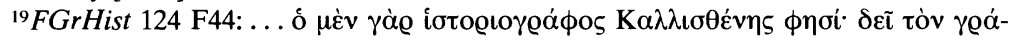

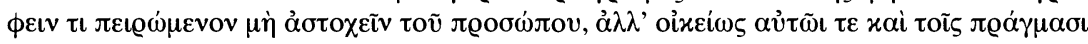

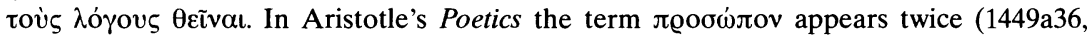
$1449 \mathrm{~b} 4)$, both times with a clearly theatrical meaning; the term $\pi \varrho \alpha \gamma \mu \alpha \tau \alpha$ also has a theatrical meaning and is widely used to describe the events that form part of the dramatic 
The adoption of this new perspective in the presentation of events must have brought with it important consequences. From its origins, Greek historiography had presupposed a continuity between historical subject matter and the reader. According to the famous formulation of Thucydides (1.22.4), the possibility that the reader might encounter or confront events like those narrated is what justifies and confers meaning on the historian's task. The concepts that historical events can be perceived to repeat themselves and that they may be foreseen create a space in which the personal experience of the reader may coexist with the material treated in the work. On both sides of the writing/reading experience, then, lie events that are interchangeable, not only in their subject matter but also in their logic. Thus a dialogue emerges between the recipient and the material that is being related, a dialogue that is, in turn, the source of the didacticism that is the raison d'être of the work.

By contrast, distancing historical events and positioning them on a plane remote from the experience of the reader/recipient obviates a direct exchange and so alters the conditions that foster dialogue and provide the base for a didactic relationship. ${ }^{20}$ In this sense it can be supposed that the Hellenistic age marked a period of crisis, change, and transformation in the field of historiography. ${ }^{21}$ If we accept this, the paradoxes we see in Theopompus' portrayals are to be interpreted as symptoms of this crisis, for they indicate that the character being portrayed is evolving on a level that is different from the normal. What is most important about this new arrangement is not the presence of figures who are out of the ordinary, but rather that their behavior and actions obey a logic, values, and principles that are distant from the circumstances and ideas that dictate the life experiences of the reader. Theopompus located his work in a realm that was separate from the

plot. This is not the occasion on which to enter into discussions concerning the birth of tragic historiography, but Callisthenes' connections with that movement have been recognized for some time: see Ullman 1942. One of the best descriptions of tragic historiography continues to be that of Walbank (1955).

${ }^{20}$ We may suppose that the new ways in which historiography was framed contributed to the move away from Thucydides that can be detected in historians of the fourth century and of the Hellenistic period. For this shift see Hornblower 1995, 60-68.

${ }^{21} \mathrm{~A}$ crisis provoked to a great extent by the difficulties of adapting historiography to new political conditions. For the historiographical difficulties posed by the great Hellenistic monarchies see the observations of Jacoby in FGrHist part IIB, commentary at 106-261, 543-44. 
everyday world. The same could be said about Timaeus' description of Agathocles and about the followers of tragic historiography and about Callisthenes. In this distancing they responded to the same literary stimuli that fostered the creation of Theocritean pastoral poetry and that located New Comedy in an ideal, imaginary city. ${ }^{22}$ The portrayal of paradoxical figures would then require abolition of the direct dialogue between reader and text and suppression of the shared space where history offers models of behavior, orients the reader on the path to be followed, and provides an education for proceeding in life.

In preparing his Life of Lysander Plutarch must have used the Hellenica of Theopompus. He includes two references to it, ${ }^{23}$ neither of which yields any information about the influence exerted; Plutarch similarly does not comment on other references to major Greek figures of the fourth century that feature in his Lives. ${ }^{24}$ But it seems certain that his literary and ideological presuppositions reveal major differences from others that surround the appearance of the paradoxical portrait. The explicit goal of the Parallel Lives is to offer models of conduct, paradigms designed to instill a desire to emulate and perform virtuous actions. ${ }^{25}$ This goal reflects a continuity between the arena in which the protagonists act and the space occupied by the reader(s). Plutarch's didacticism, his desire to offer a mirror in which readers of his biographies may measure themselves, prevents his work from becoming alien to the reality of life and excludes the distant, "dramatic" focus that seems to have influenced Hellenistic historiography. Lysander centers on a paradoxical figure, yet does so without abandoning conventions of the biographical genre or (at the other extreme) eliminating the dominant contrasts in the portrait of the protagonist. One may suppose, therefore, that Plutarch is elaborating his material in such a way that the antitheses indicative of the distanced viewpoint now take a new direction. In this process-his experiments with parallel biography-the Life of Sulla plays an important role. We shall profit from considering Sulla at some length before turning to Lysander.

${ }^{22}$ For comedy see Lanza 1993, 525-26.

${ }^{23}$ Lys. 17.3, 30.2. For Theopompus' presence in Lysander see Flacelière and Chambry $1971,162-63$.

${ }^{24}$ Nevertheless, Plutarch must have been very familiar with Theopompus, whom he mentions nineteen times in the Greek Lives and five times in the Moralia.

${ }^{25}$ See, e.g., Aem. 1.1-3, Per. 2. 


\section{SULLA}

The first chapter of the biography portrays Sulla as a character dominated by philotimia. Scion of a patrician family that had lost prestige and was impoverished, Sulla from infancy experienced a life not accordant with his social class. Philotimia, an attribute already recognized in his character by Sallust (who must have been Plutarch's source), is at the core of the traditional portrayal of Sulla, in which great public undertakings adjoin great personal defects; ${ }^{26}$ this is the origin of the verdict according to which Sulla the man is condemned while his political work is appreciated and justified. ${ }^{27}$ This portrayal is enriched with the motif of Sulla Felix, of Sulla protected by the gods, protagonist in a career favored by Fortuna. This motif, very prominent in the tradition, was apparent even in his own memoirs. ${ }^{28}$ Plutarch, who cites the work on numerous occasions, could read about it there. ${ }^{29}$ The theme of $f e$ licitas, evoked sometimes in signs indicating divine favor and sometimes in prodigia suggesting the intervention of supernatural powers in the course of events, recurs time and again throughout the biography: in the prolegomenon of the war against Mithradates, at the outbreak of the Social War, during the confrontation with Marius, in the midst of the Mithradatic conflict, and in the resumption of the civil war, when Sulla took up the dictatorship, and at his death. ${ }^{30}$

Various studies have suggested that for the author of the Parallel Lives the establishment of the Roman imperial system came in response to a providential design. ${ }^{31}$ Certainly Plutarch is neither clear nor uniform about the matter, and in the Lives, where the term tyche is frequently used as substitute for terms such as pronoia, theos, or daimonion,,$^{32}$ he is particularly elusive. Nevertheless one can find in them clear examples of the belief that a divinity directs historical events and has sponsored the birth of the Roman Empire in particular. The Greek

${ }^{26}$ Sall. Jug. 95.3-4, which Plutarch cites in Sull. 41(3).3. For an example of the antithetical assessment of Sulla see V. Max. 9.2.1.

${ }^{27}$ Laffi 1967, 265.

${ }^{28}$ Laffi 1967, 256-57; Keaveney 1982, 39-42.

${ }^{29}$ Sull. $6.8,14.10,17.2,37.1$.

${ }^{30}$ Sull. $5.8-11,6.4-13,7.3-13,9.6-8,11.1-2,14.12,17.1-4,27.6-16,28.7-12,34.3-5$, $37.2-3,38.4-5$.

${ }^{31}$ Jones 1972, 69-70; Brenk 1977, 164-65; Barigazzi 1984; Swain 1989; Swain 1996, $151-61$.

${ }^{32}$ See Brenk 1977, 146-54; Swain 1989, 273-74. 
Lives suggest that divine powers do not play a role in everyday events but do intervene in instances of change involving major implications. Thus the plague that overwhelmed Athens at the beginning of the Peloponnesian War is presented in Pericles (34.4) as a means by which the divine (to daimonion) undermines human calculations. ${ }^{33}$ In Demosthenes (19.1) and Phocion (28.2.3) Greece's subjection to Macedonia appears to be propitiated by higher forces; in the latter biography, the protagonist's virtues are of no avail against the decrees of providence. ${ }^{34}$

Rome's dominion over Greece is also a divine desideratum, according to Philipoemen (17.2-3), another biography in which the principal figure confronts divine provisions in vain. Dion and Timoleon also offer convincing examples of historical episodes that are sponsored by transcendent powers. The historical importance of Rome in Plutarch's time may explain the more frequent allusions to supernatural sanction of events in the Roman Lives, such as the birth and consolidation of Roman power, the imperial expansion, or the establishment of the principate. Romulus (8.9) and Camillus (6.3) are very explicit about the origin of Rome; Fabius (17.1) and Marcellus (3.2) mention fortune and divinity in relation to the Second Punic War; Flamininus (12.9-10) does so with regard to Roman expansion. But it is the establishment of the principate as an event of primary importance that prompts the greatest number of references to divine guidance of history: we may so interpret Pompey 53.8-10 and 75.4-5, Lucullus 44(1).1, Brutus 47.7 and 55(2).2, and Antony (55.6). ${ }^{35}$

In Sulla one does not find explicit statements about the destiny of Rome or the role of providence in history. But constant mention of prodigia at decisive junctures in Sulla's life makes it very difficult for the reader to avoid forming the impression that Sulla's career followed a plan sanctioned by the gods. To these events must be added his exploits that were distinguished by the appearance of supernatural signs concerned with the Mithradatic and civil wars. The former are treated in two other Plutarchan biographies: Lucullus, where it is repeatedly suggested that the protagonist received support from divine forces in his

${ }^{33}$ Nic. $13.5-6$ and 17.2 also allude to supernatural powers watching over the Peloponnesian War.

${ }^{34}$ See Phoc. $4-6$.

${ }^{35}$ For passages in the Lives that allude to providence see the comments of Swain $(1989,279-92)$. 
fight against Mithradates; ${ }^{36}$ and Pompey, which dedicates thirteen chapters (34-47) to the last campaigns and the death of the king of Pontus. These indicate that for Plutarch those conflicts formed a key chapter in Roman history. The civil wars, on the other hand, appear in various Lives as the necessary prologue for an event as crucial as the establishment of the principate..$^{37}$ The deeds, then, in Sulla that are embellished with allusions to providence or to transcendent powers represent fundamental events not only in the personal trajectory of the Roman general but also in the formation of the imperial system. When the biographer presents them as the result of a divine sanction tied to the life of the protagonist, he introduces into his account the historical destiny of Rome. This destiny serves as a field of significance that gathers and confers greater import upon the biographical events that are being treated. In this way the destiny of Sulla is entwined with another strand, the history of Rome. The latter bears a relationship of complicity or mutual implication with Sulla, the central figure in the work.

Thus in Sulla the destiny of Rome lurks just beneath the surface as a theme that creates tension with the biographical material and, as a foundation, lends additional significance to its elements. But Plutarch does not break with his purpose of writing biography rather than history. ${ }^{38}$ On the contrary, this tension facilitates the implementation of his biographical designs. We know that for the author of the Parallel Lives the hegemony of Rome and the regime of the principate guaranteed the maintenance of peace and harmony in the civilized world. In virtue of this, and independently of the criticisms that individual actions, measures, or personalities deserve, his work is written from a standpoint of acceptance of the Empire as a global political event. ${ }^{39}$ The repeated prodigia that adorn the career of Sulla emphasize the inscription of his deeds into the plan approved by the gods and consequently point to the Roman order, the era contemporary with Plutarch, as the goal of the trajectory that the biography follows. In this sense it is worth pointing out that the foundation on which Sulla is erected is not only the history of Rome but also the product of that history: the imperial order, Greco-Roman society, and its values.

${ }^{36}$ Luc. 3.8, 10.1, 13.5, 19.5-6, 28.7.

${ }^{37}$ See Swain 1989, 288-92.

${ }^{38}$ See Alex. 1.2 .

${ }^{39}$ See Jones 1972, 103-9, 122-30; Swain 1989, 291; see also Desideri 1992, 4482-86; Valgiglio 1992, 4046-48. 
Plutarch's look at contemporary realities, beginning with the Empire, is far from idealization. The intervals of unrest and social turbulence that he experienced at various points in his life left a profound mark on him; ${ }^{40}$ we may suppose that he viewed the existing political situation as the result of a fragile equilibrium that was always threatened. ${ }^{41}$ On the other hand, the exigencies of politics do not always coincide with morals, and the active politician can find himself forced into making sacrifices and reneging on his ethics. ${ }^{42}$ But from a biographical perspective, the fragility of the imperial system and/or its partial amorality may imply enrichment. By indicating as the horizon for his account a present worthy of preservation yet vulnerable, the biographer can seek in the life of his subject precedents not only for present values but also for present deficiencies. Thus dialogue (re)enters the narrative, and its background gains in vivacity and didactic force. So too the introduction of Rome as a reality whose dictates transcend the precepts of individual ethics prevents the biography from becoming simply an account of the virtues and vices of the individual protagonist. The scale by which Plutarch weighs and judges Sulla is not only a moral one, it is also that of his own present, with all the successes, instabilities, and contradictions which it implies. Thus a paradoxical character, illustrating both the positive traits and the negative traits of the reality that surrounds him, can serve as the center of a narrative without eliminating the didactic purpose or the dialogue between the reader and the events described.

Plutarch's projection of Sulla's biography onto the background formed by the destiny of Rome and the genesis of the contemporary world produces another important result. Russell $(1977,143)$ has pointed out that although the Parallel Lives take as their point of departure an ingenuous moral program, the execution of this initial plan goes beyond the inherent limits of the moral exemplum. Let us now take the synkrisis of Sulla and Lysander as our model for this achievement. Of its five chapters, Sulla 39(1)-43(5), the first three describe the corruption, disorderliness, and violence of Rome in the time of Sulla,

${ }^{40}$ These would have included episodes during the last days of Nero, and the trials and expulsions that occurred under Domitian: see Jones 1972, 17-18, 23-26.

${ }^{41}$ Hence the statements formulated by Dillon (1997) are hardly credible, whereby Plutarch thought that he found himself at the end of history, in a universe whose political harmony would continue until the end of the ages.

${ }^{42}$ On this point see Desideri 1995. 
and they present the moral flaws of Sulla himself, who was easily overcome by ignoble impulses. The fourth chapter exalts the scale of his military undertakings; the last chapter refocuses these exploits to present as the character's principal trait, and as the element that makes him great and glorious, his loyalty to his country and his capacity to place the public interest before his own. This Roman general has only one virtue; but Plutarch, by projecting Sulla's life onto the teleological program that led to the establishment of the Empire, executes an operation that alters the whole biography. It becomes possible to judge the protagonist on the basis of contemporary realities beyond the chronological limits of his life, and to trace a portrait that transcends the merely moral. Portrayed in these terms, Sulla appears as an individual doubly implicated in the scheme of Roman history. On the one hand, he is implicated by his links to political history, and to the greatness of Roman history. On the other, he is involved through his inability to control his passions, his cruelty, and his intemperance, evidence of the same lack of paideia-and the same grave defects that are associated with this lack - that Plutarch emphasizes in other main Roman figures. ${ }^{43}$

\section{LYSANDER}

Plutarch also draws on earlier tradition for Lysander, but in this case, unlike his treatment of Sulla, he seems to have undertaken an important task of pruning and refining. Like Sulla, the Life of Lysander makes philotimia the principle trait of its protagonist, and in doing so it coincides with the sources that preceded it. It differs from them (and from Sulla), however, in treating the origins of this central quality. Lysander's portrayal in earlier sources tends to be accompanied by explanations based upon crucial reversals or personal characteristics of the man himself. So, for example, the reference to his condition as a mothax, as a member of a lower-class family, ${ }^{44}$ can be interpreted as an

${ }^{43}$ For paideia and the important consequences of a lack of it in the Roman Lives see Swain 1990.

${ }^{44}$ This information, not gathered by Plutarch and probably false, appears in Ael. VH 12.43 and Ath. 6.102.1-14, which cites as its source the historian Philarchus of Athens (third cent. B.C.). But it is likely that its origin goes back to the fourth century. For all this, as well as for the meaning of the term mothax, see Bommelaer 1981, 36-38; Cartledge $1987,28$. 
attempt to explain his philotimia in terms of a common mechanism of ancient literature ${ }^{45}$ that of offenses stemming from inequalities of line or fortune. Aristotle (Pol. 1306b31-34) mentions the humiliations that Lysander suffered at the hands of the Spartan kings, as an example of the type of situation that engenders sedition. The kings in question are Pausanias and Agesilaus. Pausanias and his supporters managed to persuade the Spartan authorities to make Lysander return after Athens' surrender and to impose a public policy at odds with his own. ${ }^{46}$ Agesilaus counted on Lysander's support to accede to the throne, but later treated him in a humiliating way. ${ }^{47}$ The "seditions" are an allusion to the intrigue that Lysander set in motion in trying to reform the Spartan constitution so as to be able to gain the throne. ${ }^{48}$ Aristotle connected this reform with the political upsets that Lysander suffered in his country. Nepos makes the same connection (Lys. 1-3): according to the outline of this biography, Lysander defeats Athens through Athenian lack of discipline, not through his own merits. The pride produced by this victory leads him to subdue Greece with cruelty and for his own personal benefit. And when his fellow citizens call him to order, he plans to reform the constitution, inspired by motives of resentment. Diodorus' analysis (14.13) is similar, attributing Lysander's unconstitutional action to the infatuation caused by his victory over Athens.

Plutarch, on the other hand, prefers the tradition that associates philotimia with the Spartan regime. ${ }^{49}$ At the very beginning of the biography (Lys. 2.4) he declares that this quality was instilled in Lysander by his Spartan education and that nature was not an important determining factor. His treatment suppresses or glosses over elements that betray resentment. Three times he mentions that Lysander belonged to the family of the Heraclidae, ${ }^{50}$ without once mentioning alternative hypotheses. His handling of the incidents in which the Spartan kings insulted Lysander is more complex. He does not mention the confrontation with Pausanias, and the summons after the Athenian defeat is presented as resulting from the complaints of Pharnabazus, to whose

${ }^{45} \mathrm{Pl}$. Rep. 8.549c-550b; Liv. 6.34.5-10. Plutarch himself (Sull. $\left.1.2-3\right)$ resorts to this explanation.

${ }^{46}$ For this episode see Hamilton 1979, 69-85; Bommelaer 1981, 179-84.

${ }^{47}$ See Hamilton 1979, 121-24, 132-33; Bommelaer 1981, 160-61.

${ }^{48}$ Hamilton 1979, 89-95; Bommelaer 1981, 190-93, 223-25; Cartledge 1987, 94-98.

${ }^{49} \mathrm{On}$ this tradition see Pl. Rep. 8.545a-548c.

${ }^{50}$ Lys. 2.1, 7.6, 24.3-4. 
machinations are also attributed the Spartan authorities' loss of confidence in Lysander. ${ }^{51}$ Plutarch does address the change in Spartan politics that accompanied this summons, but he introduces two important variations: first, it is only when Lysander leaves his post that the kings realize the direction of his politics, and only then do they decide to alter it; second, their decision has negative consequences for Sparta, through which the Spartans return to the course begun by Lysander, so that his position is reinforced. Both variations minimize the importance of the humiliations and, consequently, drop the theme of resentment from this part of the narrative.

But Plutarch has had to manipulate the chronological sequence in order to introduce his version of events: incidents that were in fact separated by years are treated as consecutive. ${ }^{52}$ Diodorus and Nepos affirm that Lysander visited the sanctuary of Ammon after the Spartan authorities had called him and had changed the orientation of their foreign politics. Snubbed by this change, he traveled to the sanctuary in order to obtain through bribery a false oracle that would help him in his project of reforming the constitution. Plutarch relates the journey, but he affirms that it preceded the shift in Spartan politics, thereby eliminating a motivation that would reflect badly on his protagonist. ${ }^{53}$ As for the confrontation with Agesilaus, Plutarch does not hide Lysander's bitterness at the treatment he received; he links this bitterness with Lysander's intention to change the constitution. But he also introduces a number of new touches here. At first Lysander obeys Agesilaus and continues to serve Sparta loyally. It is only when the king humiliates him anew and forces him to return to Sparta ignominiously that he sets the conspiracy in motion. Furthermore, the objective that his reform pursues is presented in the narrative in a neutral tone and with a certain air of goodwill, and in an overtly exculpatory manner in the synkrisis. ${ }^{54}$ The result is that although resentment is not omitted as a theme, its impact on the reader and its capacity to mar Lysander's image are considerably reduced.

Philotimia is not the only trait that gives the biography and its central character a genuinely Spartan character. The first two chapters

${ }^{51}$ Lys. 19, 20.1-5.

${ }^{52}$ Lys. 21. On the chronological distortions evident in this part of Lysander see Flacelière and Chambry 1971, 324 ad 21.7; Hamilton 1979, n. 40.

${ }^{53}$ D.S. 14.13.2-8; Nep. 6.3.2-3; Plut. Lys. 20.8.

${ }^{54}$ Lys. 23.1-24.2, 24.3-6; Sull. 40(2).2. 
treat Sparta and present the protagonist as a product of Spartan education; the last paragraphs of the final chapter establish his honesty and mention a Spartan institution from which his daughters benefited: the men who had betrothed them, but who had reneged on the weddings when Lysander died and his poverty became known, had to pay a fine, according to an ancient law that penalized the preferment of marriage alliances with the rich over those with honorable families of one's own rank. Of the fifteen dicta put in the mouth of Lysander throughout the work, eleven are collected in the apophthegmata Laconica. ${ }^{55}$ The biography makes at least two direct allusions to the laconizing of Lysander, ${ }^{56}$ and the synkrisis ends with a eulogy of his temperance and moderation.

Early in the biography Plutarch introduces a theme that will be amply developed in the later chapters referring to the friendship between Lysander and Cyrus: he observes (Lys. 2.4) that Lysander was obliging toward the mighty to a greater extent than one would expect from a Spartan. Yet Lysander's portrayal as a timocratic man who submitted to the powerful, a product of the Spartan system, had appeared in Plato's Republic (8.549a). It is thus worth asking whether Plutarch is pointing, through this observation, not so much to a personal quality in Lysander but rather to an inconsistency in Spartan character. Something similar is going on with Lysander's propensity to resort to deceit and trickery. This trait is already present in Thucydides as a typically Spartan characteristic and is included by Plato in his timocratic-Spartan profile. ${ }^{57}$ Deception and lack of scruple are signal features in Lysander's political and military undertakings. One passage in Plutarch's rendition records his reply to those who pointed out his inconsistency, as a descendant of Heracles, in resorting to ruses de guerre: Lysander replied that where the lionskin does not reach, one should put on a foxskin. This quip recalls another Spartan sentiment, a tenet worth emphasizing. ${ }^{58}$ Later, a second saying is attributed to Lysander (this one belonging in fact to Polycrates of Samos), concerning much the same topic: one should deceive children with dice, men with oaths.

Lysander did wrong, Plutarch observes (Lys. 8.4-5), being a gen-

${ }^{55}$ See Ziegler [1951] 1965, 273.

${ }^{56}$ Lys. 23.12, 29.2.

${ }^{57}$ Thuc. 2.39.1; Pl. Rep. 8.548a. On the importance of astuteness as a Spartan attribute see also E. Andr. 445-53 and the parallel passages cited by Stevens $(1971,148)$.

${ }^{58}$ Lys. $7.6=$ apophth. Lac. 229 B. 
eral, to imitate a tyrant, and the hybris that is implicit in perjury does not fit the Spartan character. His duplicity, along with his servility, carries an element of incoherence that goes beyond the character himself. Both themes are integrated in a conjunction of motifs that runs throughout the biography and that projects an aura of ambiguity over Lysander and over Sparta. These motifs first appear at the beginning of the work, with the comment about the typically Spartan statue in the treasury of the Acanthians at Delphi-a statue that, contrary to popular opinion, does not represent Brasidas, the image of the authentic Spartan, but rather Lysander. ${ }^{59}$

Ambiguity understood in terms of false appearances or as a deceitful expectation is also present in a quotation from the comedian Theopompus, comparing the Spartans to bartenders: they gave the Greeks a taste of the sweet wine of liberty before pouring vinegar into their cup (Lys. 13.8) - a reference to the Spartan policy of enforcing oligarchic regimes, assumed at the end of the Peloponnesian War. In various places Plutarch mentions the brutality, perfidy, and lack of ethics with which Lysander, acting on behalf of Sparta, the supposed liberator of Greece, established oligarchies subject to himself. 60

Plutarch's account of Callicratidas, who succeeded Lysander as navarch, is yet another contribution to this ambivalence, this time formulated in terms of the disparity between Callicratidas' virtues and his inefficacy, as well as his positioning in contrast to the protagonist. A simple man with Doric frankness, regarded by Sparta's allies with the admiration with which one appreciates the beauty of a statue, he nevertheless lacked Lysander's zeal, his spirit of camaraderie, and the advantages of his rapacious way of dealing (Lys. 5.7-8). For his genuinely Spartan character, Callicratidas was ranked with the most notable heroes of Greece in worthiness and grandeur; but for the same reasons he disapproved of and did not adequately participate in plans to gain alliance with Persia. In the end he was defeated by the Athenians and lost his life in combat. ${ }^{61}$ Lysander, by contrast, brilliantly negotiates with the Persians; if in doing so he slips into servility, he is nevertheless capable of refusal, and his victory is the fruit of a perseverance, calcula-

${ }^{59} \mathrm{On}$ the representation of Brasidas in contrast to Lysander see the comments offered by Raaflaub $(1985,259)$.

${ }^{60}$ Lys. 7.3, 8.1-4, 13.5-9, 14.2, 19.1-6.

${ }^{61}$ Lys. 6.3-7.1. On the representation of Callicratidas as a prototypical Spartan in contrast to Lysander see Moles 1994. 
tion, prudence, and efficacy that are also in full accordance with Spar$\tan$ character. ${ }^{62}$

The ambiguity that pervades the biography reaches its most intense point in the motif of incorruptibility. Avarice and a tendency to hoard riches constitute a central trait of Plato's portrayal of Lysander (Rep. 8.548a-b), but these are absent in Plutarch's treatment. This absence is all the more notable given that Spartan covetousness seems to have been an entrenched idea among authors of the fourth century. ${ }^{63}$ Plutarch is certainly aware of the idea and exploits it abundantly in Lysander. The biography is divided into two parts. In the first (chapters 1-15), Lysander's successes and his rising career dominate; the climax is reached in the Battle of Aegospotami, acknowledged by the tradition as the beginning of Spartan hegemony. ${ }^{64}$ Plutarch highlights its importance: at the end of his account of the battle he notes that some say that what took place was the work of the gods (11.13), and he proceeds to devote an entire chapter to describing an extraordinary event, the large meteor that fell at Aegospotami. The second part (chapters 18-end), examines a succession of setbacks and misfortunes that end in the dark death of the protagonist. Chapters 16 and 17 mediate between the two parts. Chapter 16 describes how at the end of the Peloponnesian War Lysander sent to Sparta all the booty that was obtained and how Gylippus was discovered stealing part of the consignment, staining a brilliant military career through this ignoble deed. Chapter 17 reflects on Spartan covetousness, an evil that originated with the riches that Lysander introduced at the end of the war. Covetousness, then, is the turning point between the rising career of the protagonist and his political demise. At the same time, though, it is a defect in which he himself has no part. ${ }^{65}$ It is also the nucleus of the contradictions that surround him, for though he never allowed himself to be corrupted by money, his actions brought the love of money into his country, where it soon took root. ${ }^{66}$ His incorruptibility shows Lysander to be a man anchored in traditional Spartan mores, yet at the same time points up how exceptional he is,

${ }^{62}$ As an example see the description of the Battle of Aegospotami in Lys. 10-11. On the abnegation of Lysander see 4.4-6.

${ }^{63}$ See Pl. Alc. 1.122e; Arist. Pol. 1271b11-18.

${ }^{64} \mathrm{On}$ the different versions of the Battle of Aegospotami see Bommelaer 1981, 103-11; on its importance as the beginning of Spartan hegemony see Plb. 1.2.3, 1.6.1-2.

${ }^{65}$ Lysander's poverty seems to be touched on directly or indirectly at $1.2,1.6,4.5$, $18.3,30.2,30.6$.

${ }^{66}$ Lys. 2.6; Sull. 41(3).6-8. 
for it renders him immune to the new, general covetousness, an evil which-paradox upon paradox-he himself has unwittingly introduced into his homeland.

It is difficult to shed the impression that Lysander exemplifies to a great degree the contradictions that Plutarch detects in Spartan policy. Since the beginning of the Peloponnesian War, Sparta had used the liberation of Greece as a slogan for its political propaganda against Athens. From the outset, doubts arose about the sincerity of this-doubts that soon were heightened, and for two reasons. First, the course of the war required Spartan authorities to intervene more and more in the internal politics of states that were allied or captured by the Athenian league. The introduction of oligarchic regimes was accompanied by the establishment of garrisons under the command of a Spartan official according to a practice that carried on beyond the final victory over Athens. Second, during the last years of the war Sparta had to approach Persia; in exchange for financial and military assistance, Sparta recognized the Persian king's rights to the territories in Asia occupied by Greek cities. The deterioration of Sparta's repute is already reflected in Thucydides ${ }^{67}$ and is echoed in passages of later literature that accuse Sparta of (among other evils) oligarchic tendencies, duplicity, cruelty, perfidy, injustice, and betrayal of Greek interests. ${ }^{68}$ All of these flaws also characterize the political activity of Plutarch's Lysander. ${ }^{69}$

The identification of Lysander with Sparta can also be seen in the general structure of the biography. After the digression about the introduction of money into Sparta and the consequent corruption of its constitution and customs, the second part of the work, dedicated to the demise of Lysander, very significantly begins with an allusion to the Battle of Leuctra (Lys. 18.1). This battle, in 371, came to represent the disappearance of Sparta as the leading power in Greece; its mention at this point indicates how the collapse of Spartan hegemony becomes a hori-

${ }^{67}$ See Raaflaub 1985, 248-57.

${ }^{68}$ Xen. $H G$ 6.3.7-9; Isoc. 4.104-6, 4.110ff., 12.102-6. Criticism of the Spartan hegemony is a fundamental idea in the Hellenica Oxyrhynchia, as long since recognized by Jacoby FGrHist part IIC, commentary on 64-105, 7 (see also Schepens 1993, 182, 197).

${ }^{69}$ Another character intimately connected with Spartan history of these years, Agesilaus, also serves as the protagonist of a biography that is interwoven with ambiguity and in which the harmful consequences of Spartan policy come to the fore: see Ages. 23, 26,30 . 
zon that enfolds the biography. Momigliano (1935a, 1935b) has pointed out that the events at Leuctra had an immense impact on the interpretation and historiography of the fourth century. Up to that point the hegemony of the Greek world had fallen to Athens and Sparta. Both had held the leadership of Greece not only on a political plane but also on an ethical and cultural plane, being the originators of constitutions and educational systems that became paradigmatic. Their decline was accompanied by the rise of new powers that did not represent any recognized political or moral ideal and whose function was purely negative, since it consisted in dissolving the order created around Athens and Sparta. This disruption created a climate of uncertainty, disorder, and perplexity, an atmosphere of confusion which is reflected in different ways in Xenophon's Hellenica, Ephorus' Historia, and Theopompus' Hellenica. Jacoby (1919) observes that this same feeling of crisis was explored in Callisthenes' Hellenica (composed ca. 340), which covered in ten books the events between 387/86 (the Peace of Antalcidas) and 357/56 (episodes leading up to the Third Sacred War). A fundamental element in the organization of this narrative was the idea that during this period the affairs of Greece had degenerated into disorder and anarchy. ${ }^{70}$

The fabric of Plutarch's Lysander, then, is invested with the history of Sparta. False appearances (an inherent quality in a regime that would favor liberty but take steps to subject the cities supposedly liberated), the use of methods that contradict their objectives, the establishment of an international order that cannot be sustained, the betrayal of Greek interests-all are themes in the narrative that extend beyond the character to a concern with the history of his country. The end of the biography, with the decline of its central subject and his less than brilliant death, finds a parallel in the Battle of Leuctra. The moral perplexities, the atmosphere of crisis and confusion surrounding Leuctra, are projected over the Life of Lysander and place its protagonist in a context that is scarcely favorable to Plutarch's authorial task of revealing ethical essentials and seeking paradigms in the biographies of eminent persons. Resorting to the parallel Life, that of Sulla, helps us to a clearer perspective. Let us return there.

${ }^{70}$ Jacoby 1919, 1698. On the date of composition for Callisthenes' Hellenica see FGrHist ad 124 F8-13, and Prandi 1985, 38. 


\section{PLUTARCH'S ROMAN PERSPECTIVE}

Sulla begins with a clear and traditional explanation (inequality between lineage and fortune) for the man's central characteristic, his philotimia. The second chapter contains an illustrative physical description, indicates his principal character traits, and makes first mention of his fondness for the pleasures of drinking, entertainment, and a prodigal lifestyle - a theme that will recur in later chapters. Thus the personal image of the Roman general acquires, right from the start, a sharpness of focus that contrasts with that of his Greek counterpart, and the biography as it unfolds helps to accentuate this difference. The character and actions of Lysander show a disconcerting mix of virtues and defects, as does the political trajectory of Sparta. With Sulla, on the other hand, the historical dimension is superimposed onto the human profile without becoming admixed, such that his political greatness and his culpable personal disposition coexist in a neat dichotomy. Thus the Roman biography, with its clear separation between the two facets of its subject's personality, provides the mold by which Lysander, protagonist of the parallel Greek biography, is measured. But in these paired portraits we may detect something more than a progression in the accentuation of negative traits or an application of the cumulative descriptive procedure that has been called "redefinition." 71

In the synkrisis for these two Lives Plutarch achieves a balanced evaluation that distinguishes between Lysander's good qualities and defects. We may infer that it is here that the reference points are supplied that are necessary to diffuse the ambivalence and atmosphere of ethical confusion that dominate in Lysander. The synkrisis does not merely compare Sulla and Lysander; with each subject now firmly embedded, through his biography, in the history and destiny of his respective country, it also invites a comparison of Roman and Spartan histories. The biographer adopts the perspective attributed to Rome. This stance, already implicit in Sulla, is confirmed explicitly in the chapter (42[4]) that extols the transcendence of his achievement and downplays the politi-

${ }^{71}$ As defined by Pelling (1986, 96; 1988b, 12-15), redefinition is a technique whereby an author proceeds first with a rough general description of a certain character in order to complete the portrayal later in a finer, more detailed and individualizing manner, a movement toward refinement that becomes more penetrating as the narrative proceeds. This tactic enjoyed a long tradition, in which Plutarch often, though not always, plays an important role. 
cal enterprises of his Greek counterpart. In this way Plutarch clinches his acceptance of Rome as the guiding principle that informs the course of history: the Roman present, the logical culmination of this history, is adopted as the perspective necessary for measuring the past. From this standpoint, as we have seen, Sulla's contrasts are explained, if not dismissed, by connecting them with live and current realities.

Something similar also occurs for Lysander, whose antitheses also carry a significant message for the contemporary world. Certainly the message is the inverse of the one conveyed by Sulla's Roman Life. Lysander speaks of hegemony set up in terms of oppression and deceit, of a political project that is dominated by the tyranny of one set of Greeks over another. At the same time, its protagonist embodies virtues-sobriety, incorruptibility, temperance-typical of Spartan upbringing and tradition that remained fully alive in the time of Plutarch. Thus the paradoxical condition of one or the other character is introduced into two different domains, each producing different though symmetrical results: political greatness and an unstable personal disposition in the case of Sulla, political failure along with appreciable personal qualities in that of Lysander.

To reach this verdict Plutarch has opened up an axiological universe whose principles are alive in the narrative itself but also outside it, in the world in which the author and his public live. For only by supporting it with solid points of reference can he succeed in the task of approximation, dissection, framing, and clarification that weighs traits and confers significance on the contrasts of his characters. The Life of Sulla brings Roman history up to date; it signals the setting of the biographer in the present that arises from that history and ensures that the principles of contemporary society are established in the necessary points of reference. Thus it is worth pointing out, as Stadter does, that the figure of Sulla allows us to understand that of Lysander.

On the other hand, as Pelling might prefer to emphasize, Lysander is an integrated character. But if we accept that coherence with the world around us and the capacity to present a portrayal that can be identified with the experience of the reader are part of the integration, we must also admit that in order to create an integral character Plutarch operates in a way that makes possible the contiguity between account and reader and permits the dialogue that the reader maintains with the work. This dialogue offers a wide and varied axis for discussion, as it does not merely focus on moral matters. To a great extent, its point of departure is the sociopolitical realities that formed Plutarch's 
world, and the Greek and Roman past where they had their origins. In this dialogue the presentation of both biographical subjects as individuals tied to the plot of Greek and Roman history assumes a central importance. And in this respect, it is significant that the synkrisis should end by dealing with two complementary elements, each proceeding from a source that fed the cultural landscape of the author of the Parallel Lives: Greek paideia, represented in the temperance and moderation that the Spartan agōge of Lysander illuminates; and the historical destiny of Rome, toward which the military exploits of Sulla point. ${ }^{72}$

UNIVERSIDAD DE SEVILLA

e-mail: jcandau@siff.us.es

\section{BIBLIOGRAPHY}

Barigazzi, Adelmo. 1984. "Plutarco e il corso futuro della storia." Prometheus 10:264-86.

Bommelaer, Jean. 1981. Lysandre de Sparte: histoire et traditions. Paris: De Boccard.

Brenk, Frederick. 1977. In Mist Apparelled: Religious Themes in Plutarch's Moralia and Lives. Leiden: Brill.

Brown, Truesdell. 1973. The Greek Historians. Lexington, Mass., and Toronto: D. C. Head.

Cartledge, Paul. 1987. Agesilaos and the Crisis of Sparta. Baltimore: The Johns Hopkins University Press.

Connor, W. R. 1967. "History without Heroes: Theopompus' Treatment of Philip of Macedon." GRBS 8:133-54.

. 1968. Theopompus and Fifth-Century Athens. Washington, D.C.: Center for Hellenic Studies.

Desideri, Paolo. 1992. "Le formazione delle coppie nelle Vite plutarchee." ANRW II.33.6 4470-86.

- 1995. "Teoria e prassi politica nelle opere di Plutarco." In Atti del V Convegno plutarcheo (Certosa di Pontignano, 7-9 giugno 1993), edited by Italo Gallo and Barbara Scardigli, 107-22. Naples: M. D'Auria.

Dillon, John. 1997. "Plutarch and the End of History." In Plutarch and His Intellectual World, edited by Judith Mossman, 233-40. London: Duckworth.

${ }^{72}$ This essay was begun at the University of North Carolina at Chapel Hill during a period of research funded by the Spanish Ministry of Education that lasted from September until December 1997 (PR97 28335032K). My conversations there with Philip Stadter contributed substantially to clarifying my ideas about Plutarch; all the shortcomings of this writing, however, are mine. 
Duff, T. 1997. "Moral Ambiguity in Plutarch's Lysander-Sulla." In Plutarch and His Intellectual World, edited by Judith Mossman, 169-88. London: Duckworth.

Flacelière, Robert, ed., and Emile Chambry, trans. 1971. Plutarque: Vies. Vol. VI, Pyrrhos-Marius/Lysandre-Sylla. Paris: Les Belles Lettres.

Goldhill, Simon. 1990. "Character and Action, Representation and Reading: Greek Tragedy and Its Critics." In Characterization and Individuality in Greek Literature, edited by Christopher Pelling, 100-128. Oxford: Clarendon Press.

Hamilton, Charles. 1979. Sparta's Bitter Victories: Politics and Diplomacy in the Corinthian War. Ithaca and London: Cornell University Press.

Hornblower, Simon. 1995. "The Fourth-Century and Hellenistic Reception of Thucydides." JHS 115:47-68.

Jacoby, Felix. [1909] 1956. "Über die Entwicklung der griechischen Historiographie und den Plan einer neuen Sammlung der griechischen Historikerfragmente." Klio 9:80-123. Reprinted in Abhandlungen zur griechischen Geschichtsschreibung. Leiden: Brill.

. 1919. "Kallisthenes von Olynth." RE X.2 1674-1707.

Jones, Christopher. 1972. Plutarch and Rome. Oxford: Clarendon Press.

Keaveney, Arthur. 1982. Sulla: The Last Republican. London: Croom Helm.

Laffi, Umberto. 1967. "Il mito di Silla: Parte II." Athenaeum 45:255-77.

Lanza, Diego. 1993. "Menandro." In Lo spazio letterario della Grecia antica. Vol. I, La produzione e la circolazione del testo. Tomo II, L'Ellenismo, edited by Giuseppe Cambiano, Luciano Canfora, and Diego Lanza, 501-26. Rome: Salerno.

La Penna, A. 1976. "Il ritratto paradossale da Silla a Petronio." RFIC 104: 270-93.

Lehmann, Gustav. 1974. "Polybius und die ältere und zeitgenössische griechische Geschichtsschreibung." In Polybe, 146-200. Entretiens sur l'Antiquité Classique, 20. Geneva: Vandoeuvres.

Moles, John. 1994. "Xenophon and Callicratidas." JHS 114:70-84.

Momigliano, Arnaldo. 1935a. "L'egemonia tebana in Senofonte e in Eforo." $A \& R$ 3:101-17.

. 1935b. "La Storia di Eforo e le Elleniche di Teopompo." RFIC 13: 180-204.

Pearson, Lionel. 1987. The Greek Historians of the West: Timaeus and His Predecessors. Atlanta: American Philological Association.

Pédech, Paul. 1961. Polybe: Histoires. Livre XII. Paris: Les Belles Lettres.

Pelling, Christopher. 1986. "Synkrisis in Plutarch's Lives." In Miscellanea Plutarchea: Atti del I Convegno di Studi su Plutarcho, edited by Frederick Brenk and Italo Gallo, 83-96. Ferrara: Giornale Filologico Ferrarese.

. 1988a. "Aspects of Plutarch's Characterisation." ICS 13:257-74.

. ed. and trans. 1988b. Plutarch: Life of Antony. Cambridge: Cambridge University Press. 
1990a. "Childhood and Personality in Greek Biography," "Conclusion." In Characterization and Individuality in Greek Literature, edited by Christopher Pelling, 213-44. Oxford: Clarendon Press.

- 1990b. "Conclusion." In Characterization and Individuality in Greek Literature, 245-62.

Prandi, Luisa. 1985. Callistene: uno storico tra Aristotele e i re macedoni. Milan: Jaca Books.

Raaflaub, Kurt. 1985. Die Entdeckung der Freiheit: zur historischen Semantik und Gesellschaftsgeschichte eines politischen Grundbegriffes der Griechen. Munich: Beck.

Russell, D. A. 1966. “On Reading Plutarch's Lives.” G\&R 13:139-54.

Schepens, Guido. 1993. "L'apogée de l'archē spartiate comme époque historique dans l'historiographie grecque du début du IVe s. av. J-C." AncSoc 24:169-203.

Schwartz, Eduard. 1905a. "Diodoros." RE V 663-704. 1905b. "Duris." $R E \mathrm{~V}$ 1853-56.

Shrimpton, Gordon. 1991. Theopompus the Historian. Montreal and Buffalo: McGill-Queens University Press.

Stadter, Philip. 1992. "Paradoxical Paradigms: Lysander and Sulla." In Plutarch and the Historical Tradition, edited by Philip Stadter, 41-55. London and New York: Routledge.

. 1997. "Plutarch's Lives: The Statesman as Moral Actor." In Plutarco y la historia: Actas del V Simposio Español sobre Plutarco, edited by Carlos Schrader, Vicente Ramón, and José Vela, 65-81. Monografías de Filología Griega. Zaragoza: Area de Filología Griega, Departamento de Ciencias de la Antigüedad, Universidad de Zaragoza.

Stevens, P. T. 1971. Euripides: Andromache. Oxford: Clarendon Press.

Strasburger, Hermann. 1977. "Umblick im Trümmerfeld der griechischen Geschichtsschreibung." In Historiographia Antiqua: Commentationes Lovanienses in Honorem W. Peremans Septuagenarii Editae, 3-52. Leuven: Leuven University Press.

Swain, Simon. 1989. "Plutarch: Chance, Providence, and History." AJP 110: 272-302.

1990. "Hellenic Culture and the Roman Heroes of Plutarch." JRS 110: 126-45.

1996. Hellenism and Empire: Language, Classicism, and Power in the Greek World, A.D. 50-250. Oxford: Clarendon Press.

Ullman, B. L. 1942. "History and Tragedy." TAPA 73:25-53.

Valgiglio, Ernesto. 1992. "Dagli 'Ethicà' ai 'Bioi' in Plutarco." $A N R W$ II.33.6 3963-4051.

Vattuone, Riccardo. 1991. Sapienza d'occidente: il pensiero storico di Timeo di Tauromenio. Bologna: Pàtron.

Walbank, F. W. 1955. "Tragic History: A Reconsideration.” BICS 11:4-14.

Ziegler, Konrat. [1951] 1965. "Plutarchos von Chaironeia." RE XXI.1 636-962. Translated by Maria R. Zancan Rinaldini as Plutarco. Brescia: Paideia. 